\title{
Assessment of climate change impacts on agricultural sector in Vinh Long province
}

\author{
Le Ngoc Tuan, Tran Thi Thuy
}

\begin{abstract}
Climate change is one of the major challenges for humanity in the $21^{\text {st }}$ century, has negatively affected many sectors. This work aimed at assessing impacts of climate change (CC) on agricultural sector in Vinh Long province till 2020 via data collection and processing method, Geographic Information System (GIS), risk assessment matrix, and SWOT. Flood, saltwater intrusion (SI), drought, landslide, storm, temperature, and precipitation were taken into consideration. Flood, SI, and temperature were found as main factors affecting on agricultural sector in Vinh Long province, especially rice. In Vinh Long province, Vung Liem, Long Ho, and Binh Tan districts were significantly effected. Besides, this work proposed some solutions to improve the adaptive capacity to $\mathrm{CC}$ of this sector, contributing to the local sustainable development.
\end{abstract}

Index Terms - Agriculture, climate change, saltwater intrusion, flood

\section{INTRODUCTION}

C limate change is one of the major challenges for humanity in the 21st century. Disasters and severe weather events are increasing in quantity, strength, and affecting scale, considered as top concerns of the world, including VietNam, especially in the MeKong Delta where would be in danger of flooding about $39 \%$ of the area under sea level rise $1 \mathrm{~m}$ [1]. Therefore, both positive and negative impacts of CC need assessing to develop suitable adaption plans.

Agriculture is a sensitive sector to climatic conditions and disasters, such as temperature, precipitation, SI, drought, and flood, etc., thus can be seriously affected by CC [2-6].

Received:10-04-2017, Accepted:15-09-2017, Published: 1008-2018

Author: Le Ngoc Tuan- University of Science, VNU-HCM (e-mail: Intuan@hcmus.edu.vn). Tran Thi Thuy-Institute of Meteorology, Hydrology and Environment
Many different methods have been used to assess impacts of CC on agricultural sector, based on the historical climate data [7], modelling as DSSAT Ver 4.0.2 model (Decision Support System for Agrotechnology Transfer) [8 - 10], AquaCrop [11, 12], Cropwat [13], etc., lab-scale empirical methods for annual and perennial crops, pests, and epidemics [14], GIS and remote sensing [14], expert method, and community survey [15, 16]. In general, according to research objectives and scope, suitable individual or combined methods are used.

Vinh Long province (including Vinh Long city, Vung Liem, Mang Thit, Tra On, Tam Binh, Binh Tan, Binh Minh, and Long Ho districts), located in the Mekong Delta, on one hand has a thriving agriculture sector, especially rice, fruit, and freshwater aquaculture with about $79 \%$ of its natural area being agricultural land [17]. On the other hand, it also would be one of the most flooding area in the context of sea level rise [1]. Besides, natuaral disasters such as riverbank landslide, storm, drought, SI, etc. have occured quite frequently [18] and then seriously affected the local agricultural sector, especially in the context of CC.

Therefore, assessing CC impacts on agricultural sector is necessary to provide scientific basis for developing adaptive solutions in each specific condition, reducing risks, and contributing to the local sustainable development.

\section{METHODS}

Impacts of $\mathrm{CC}$ on the agricultural sector of Vinh Long province were assessed by the effects of flood, SI, drought, storm, temperature, and precipitation variations (called as CC factors in this work).

\section{Data collection and processing method}

Concerning data of the current status and development plans of the agricultural sector, the changing in disasters and climate, CC scenarios (developed by SIMCLIM software according to AR4 of IPCC), SI and tidal flooding scenarios, as well as response action plans, etc. was collected, 
then processed by Excel software. For CC scenarios in VinhLong province in 2020, according to the average greenhouse gas emission scenario (B2), temperature and precipitation would be $27.64^{\circ} \mathrm{C}$ and $1,491.80 \mathrm{~mm}$, respectively; water level would rise about $9 \mathrm{~cm}$ as compared to that in the reference period (1980-1999) [19].

\section{Geographic Information System (GIS) method}

Mapinfo 11.5 and ArGIS softwares were used to mapping impacts of flood, SI, temperature, and precipitation, etc. on agricultural sector in Vinh Long province to 2020.

\section{$\mathrm{CC}$ risk assessment matrix}

This method was used to determine areas needing to be paid special attention and respective causes based on the risk level due to $\mathrm{CC}$ which was evaluated by risk index as presented in Table 1 .

Table 1. Risk index scale due to CC

\begin{tabular}{|c|c|c|c|c|}
\hline $\begin{array}{c}\mathbf{0}<\mathbf{R R} \leq \\
\mathbf{1}\end{array}$ & $\begin{array}{c}\mathbf{1}<\mathbf{R R} \\
\mathbf{\leq}\end{array}$ & $\begin{array}{c}\mathbf{2}<\mathbf{R R} \leq \\
\mathbf{3}\end{array}$ & $\begin{array}{c}\mathbf{3}<\mathbf{R R} \\
\mathbf{5}\end{array}$ & $\begin{array}{c}4<\mathbf{R R} \leq \\
\mathbf{5}\end{array}$ \\
\hline Very low & Low & Average & High & $\begin{array}{c}\text { Very } \\
\text { high }\end{array}$ \\
\hline
\end{tabular}

The risk index to CC was integratedly calculated by risk index to each $\mathrm{CC}$ factor (basically determined based on occurrence possibility and related damages) and its weight in relation to the agricultural sector.

The weight of each CC factor was determined as follows:

- Ranking the importance of each factor based on 20 experts' opinions. The more important the factor is, the higher the ranking score will be.

- Determining the ranking score of each factor (mi): $\mathrm{m}_{\mathrm{i}}=\mathrm{M}_{\mathrm{i}} / \mathrm{n}$ where $\mathrm{M}_{\mathrm{i}}$ is total score of factor $i$ and $n$ is number of questionaires.

- Calculating the intermediate weight of each factor $\left(w^{\prime}{ }_{i}\right)$ : (i) for the factor having the lowest $\mathrm{m}_{\mathrm{i}}$, accepting its $\mathrm{w}_{\mathrm{i}}=1.0$; (ii) calculating $\mathrm{w}^{\prime}{ }_{\mathrm{i}}$ of other factors: $\mathrm{w}^{\prime}{ }_{\mathrm{i}}=$ $\mathrm{m}_{\mathrm{i}(\min )} / \mathrm{m}_{\mathrm{i}}$

- Calculating the final weight of each factor $\left(\mathrm{w}_{\mathrm{i}}\right)$ :

$$
\mathrm{w}_{i}=\frac{w_{i}{ }^{\prime}}{\sum_{1}^{n} w_{i}{ }^{\prime}}
$$

SWOT method (S-Strengths; W-Weaknesses; O-Opportunities; T-Threats)
SWOT was used to determine causes and corresponding adaption measures: (i) determing $\mathrm{S}$ and $\mathrm{W}$ of the agricultural sector in Vinh Long province; (ii) determining $\mathrm{O}$ and $\mathrm{T}$ of external factors in relation to $\mathrm{CC}$; (iii) Analysing and combining suitable pairs (S-O, S-T, W-O, W-T), then determing defective chains and proposing adaptive measures.

\section{RESULTS AND DISCUSSION}

Current status and the development plan of the agricultural sector in Vinh Long province till 2020

Current status: for the period of 2005-2015, reverse with the planting sector, the proportion of the breeding sector and service agricultural activities was increased. However, the planting sector still held the leading role, accounting for $67.78 \%$ of the agricultural sector in 2015 (followed by breeding sector and service agricultural activities, according to $26.46 \%$ and $5.76 \%$ ), including major crops such as rice, annual crops, fruit and perennial plants. The largest areas of rice and fruit in the province were mainly located in Vung Liem, Tra On, Tam Binh, and Mang Thit districts [17].

Development plan: The agriculture, forestry, aquaculture sector of Vinh Long province has strived to achieve the growth rate of 4.0-4.5\%/year in the period of 2016-2020, reducing the proportion of planting sector but conversely for the breeding sector. By 2020, the proportion of planting sector, breeding sector, and agricultural services are $61.91 \%, 32.92 \%$, and $5.17 \%$, respectively. Besides, it is oriented to reduce the rice land instead of fruit land, to reduce the third crop of rice, to increase the alternation of crops, to exploit the strengths of fruit and aquaculture [20].

\section{Assessment of CC impacts on agricultural sector in Vinh Long province}

\section{Temperature}

Maximum temperature fluctuated in $35^{\circ} \mathrm{C}-$ $36.5^{\circ} \mathrm{C}$ (in the period of $1986-2005$ ) and affected about 5,000 ha of agricultural land, corresponding to $65.9 \%$ and $34.1 \%$ of the annual and perennialplant land, mainly distributed in Binh Tan (about 2,000 ha), followed by Long Ho, Mang Thit, Vung Liem districts (about 500-600 ha).

By 2020, temperature will be increased but the affected agricultural land could be decreased due to the change in agricultural land-use planning as 
mentioned: about 3,163 ha, mainly in Binh Tan district (about $32 \%$ of affected area).

\section{Precipitation}

Heavy, erratic, and unseasonal rain create favorable conditions for pest development. In the context of $\mathrm{CC}$, the epidemics are increasingly complex, such as brown backed plant hopper, rice blast disease, sheath blight disease, leaf roller disease, twisted leaf disease, yellow leaf disease, yellow dwarf disease, etc. and affect the ability of intensive farming in Mekong Delta as well as VinhLong province [21].

\section{Flooding}

Flooding has the most impacts on rice-land and perennial-plant land in the province (Table 2). On one hand, it causes the decrease in agricultural yield and product quality, consequently provincial gross domestic product. On the other hand, it results in alluvium and then fertility for soil, etc.

Current status: rice-land (LUC) and perennialplant land (CLN) have been significantly affected by flooding: about 24,500 ha (accounted for $27 \%$ of agricultural land of the province), mainly located in Vung Liem (about 7,327 ha, accounted for $40.7 \%$ of agricultural land of the district), Long Ho (about 3,867 ha, 37.4\%) and Tam Binh district (3,175 ha, $16.8 \%)$ (Table 2).

In 2020, flooded agricultural land could be decreased due to the change in rice land-use planning: about 23,394 ha, $29.8 \%$. Vung Liem, Long Ho, and Tam Binh districts would be still affected the most, thus need suitable adaption measures (Fig. 1, Table 2).

\section{Saltwater intrusion}

Sea water entering inland can impact crops as making flower and fruit loss during blooming and fruiting periods, even killing plants due to high salinity of water. Besides, salinity reduces planting area, leading to the decrease in crops yield. Calculated results showed that VungLiem district is always the most affected in the current status and 2020 - B2 scenario (Fig. 2, Table 3)

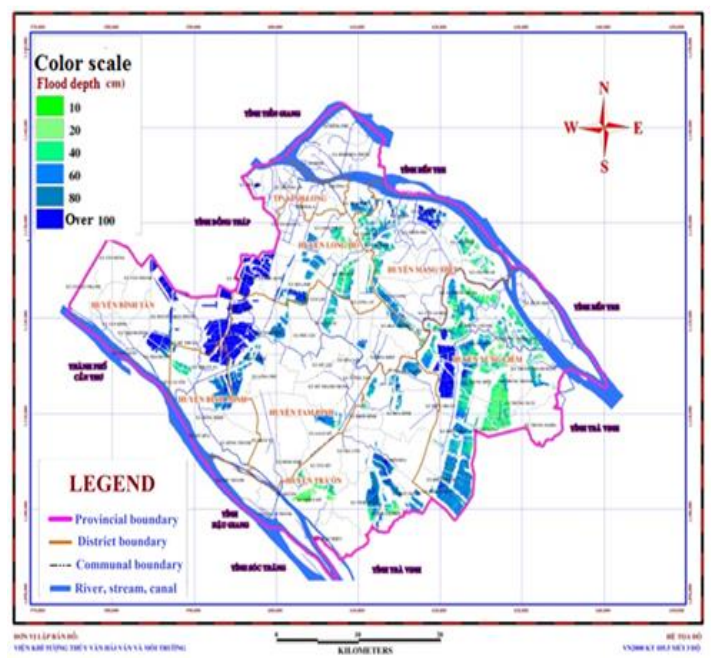

Fig. 1. Flooded rice-land in Vinh Long province in 2020 


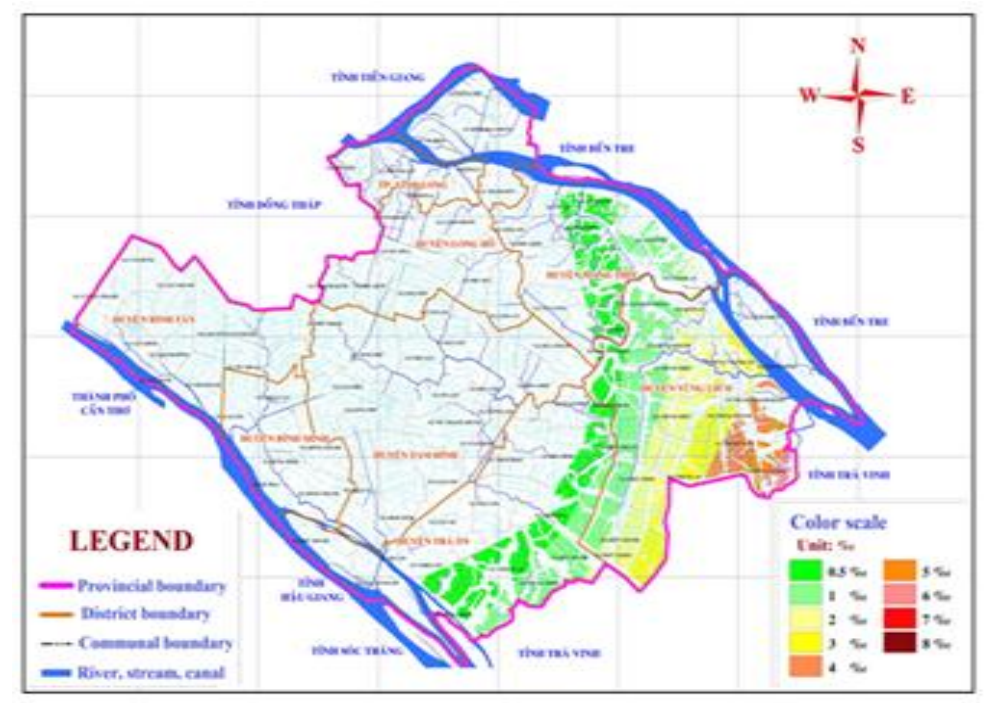

Fig. 2. Salt-intruded rice-land in Vinh Long province till 2020

Table 2. Area (ha) having the risk of flood in current status and 2020 - B2 Scenario

\begin{tabular}{|c|c|c|c|c|c|c|c|c|c|c|c|}
\hline & & & $\begin{array}{c}\text { Binh } \\
\text { Minh }\end{array}$ & $\begin{array}{l}\text { Binh } \\
\text { Tan }\end{array}$ & Long Ho & Mang Thit & Tam Binh & $\begin{array}{c}\text { Vinh } \\
\text { Long city }\end{array}$ & Tra On & $\begin{array}{l}\text { Vung } \\
\text { Liem }\end{array}$ & Total \\
\hline \multirow{6}{*}{$\begin{array}{c}\text { Rice - } \\
\text { land }\end{array}$} & \multirow{3}{*}{ Current } & Total & $3,946.8$ & $9,618.5$ & $6,779.0$ & $6,953.2$ & $16,750.6$ & 464.4 & 12,101 & $14,790.9$ & $71,404.7$ \\
\hline & & Flooded & $1,465.6$ & $2,050.4$ & $2,909.1$ & $1,713.1$ & $2,886.9$ & 107.8 & $2,141.2$ & $6,680.2$ & $19,954.3$ \\
\hline & & $\%$ & 37.1 & 21.3 & 42.9 & 24.6 & 17.2 & 23.2 & 17.7 & 45.2 & 27.9 \\
\hline & \multirow{3}{*}{2020} & Total & $2,986.9$ & $8,376.4$ & $5,806.7$ & $6,161.1$ & $15,877.5$ & 292.2 & $11,453.1$ & $13,527.3$ & $64,481.2$ \\
\hline & & Flooded & $1,084.1$ & $1,733.4$ & $2,607.3$ & $1,839.1$ & $2,650.6$ & 26.6 & $2,327.1$ & $7,581.9$ & $19,850.1$ \\
\hline & & $\%$ & 36.3 & 20.7 & 44.9 & 29.8 & 16.7 & 9.1 & 20.3 & 56.1 & 30.8 \\
\hline \multirow{6}{*}{$\begin{array}{c}\text { Perennial } \\
\text { plant - } \\
\text { land }\end{array}$} & \multirow{3}{*}{ Current } & Total & $1,581.4$ & $1,012.8$ & $3,566.1$ & $2,045.8$ & $2,152.1$ & $1,235.6$ & $4,423.8$ & $3,200.7$ & $19,218.3$ \\
\hline & & Flooded & 879.6 & 115.4 & 957.6 & 404.2 & 288.1 & 577.5 & 674.4 & 646.4 & $4,542.9$ \\
\hline & & $\%$ & 55.6 & 11.4 & 26.8 & 19.8 & 13.4 & 46.7 & 15.2 & 20.2 & 23.6 \\
\hline & \multirow{3}{*}{2020} & Total & 988.2 & 697.8 & $2,931.8$ & $1,610.6$ & $1,773.7$ & 37.8 & $3,464.2$ & $2,625.2$ & $14,139.4$ \\
\hline & & Flooded & 579.3 & 76.5 & 970.0 & 457.2 & 245.7 & 4.8 & 532.2 & 678 & $3,543.7$ \\
\hline & & $\%$ & 58.6 & 10.9 & 33.1 & 28.4 & 13.8 & 12.8 & 15.4 & 25.8 & 25.1 \\
\hline \multirow{6}{*}{ Total } & \multirow{3}{*}{ Current } & Total & $5,528.2$ & $10,631.3$ & $10,345.1$ & $8,999.1$ & $18,902.8$ & $1,700.1$ & $16,524.8$ & $17,991.6$ & 90,623 \\
\hline & & Flooded & $2,345.2$ & $2,165.9$ & $3,866.6$ & $2,117.3$ & $3,174.9$ & 685.3 & $2,815.6$ & $7,326.5$ & $24,497.3$ \\
\hline & & $\%$ & 42.4 & 20.4 & 37.4 & 23.5 & 16.8 & 40.3 & 17 & 40.7 & 27 \\
\hline & \multirow{3}{*}{2020} & Total & $3,975.1$ & $9,074.3$ & $8,738.4$ & $7,771.7$ & $17,651.2$ & 330 & $14,917.3$ & $16,152.5$ & $78,620.6$ \\
\hline & & Flooded & $1,663.4$ & $1,809.8$ & $3,577.4$ & $2,296.2$ & $2,896.3$ & 31.4 & $2,859.3$ & $8,259.9$ & $23,393.8$ \\
\hline & & $\%$ & 41.8 & 19.9 & 40.9 & 29.6 & 16.4 & 9.5 & 19.2 & 51.1 & 29.8 \\
\hline
\end{tabular}

Table 3. Area (ha) of rice land and perennial plant land affected by SI

\begin{tabular}{|c|c|c|c|c|c|c|c|c|}
\hline \multirow{2}{*}{\multicolumn{3}{|c|}{ Object }} & \multicolumn{3}{|c|}{ Current } & \multicolumn{3}{|c|}{2020} \\
\hline & & & Mang Thit & Tra On & Vung Liem & Mang Thit & Tra On & Vung Liem \\
\hline \multirow{5}{*}{$\begin{array}{l}\text { Salt-intruded } \\
\text { rice-land }\end{array}$} & \multirow{2}{*}{$\geq 2 \mathrm{~g} / \mathrm{L}$} & ha & - & - & $7,002.9$ & 123.4 & 42.6 & $9,083.6$ \\
\hline & & $\%$ & - & - & 47.2 & 2.0 & 0.4 & 66.9 \\
\hline & \multirow{2}{*}{$\geq 4 \mathrm{~g} / \mathrm{L}$} & ha & - & - & 767.3 & - & - & $2,032.3$ \\
\hline & & $\%$ & - & - & 5.2 & - & - & 15.0 \\
\hline & \multicolumn{2}{|c|}{$\begin{array}{c}\text { Total area (ha) of } \\
\text { rice-land }\end{array}$} & $6,953.8$ & $12,067.4$ & $14,824.1$ & $6,206.2$ & $11,386.4$ & $13,584.1$ \\
\hline \multirow{7}{*}{$\begin{array}{l}\text { Salt-intruded } \\
\text { perennial plant- } \\
\text { land }\end{array}$} & \multirow{2}{*}{$\geq 2 \mathrm{~g} / \mathrm{L}$} & ha & - & - & $2,062.5$ & 226.1 & 6.7 & $2,038.8$ \\
\hline & & $\%$ & - & - & 64.4 & 14.1 & 0.2 & 77.6 \\
\hline & \multirow{2}{*}{$\geq 4 \mathrm{~g} / \mathrm{L}$} & ha & - & - & 257.4 & - & - & 834.4 \\
\hline & & $\%$ & - & - & 8.0 & - & - & 31.9 \\
\hline & \multirow{2}{*}{$\geq 7 \mathrm{~g} / \mathrm{L}$} & ha & - & - & - & - & - & 2.6 \\
\hline & & $\%$ & - & - & - & - & - & 0.1 \\
\hline & \multicolumn{2}{|c|}{$\begin{array}{c}\text { Total area (ha) of } \\
\text { perennial plant - land }\end{array}$} & 2,041.8 & 2,041.8 & $4,443.4$ & $3,201.8$ & $1,607.6$ & $3,476.5$ \\
\hline
\end{tabular}


Table 4. CC risk index of agricultural sector in Vinh Long province

\begin{tabular}{|c|c|c|c|c|c|c|c|c|c|c|}
\hline & & $\begin{array}{c}\text { Temper- } \\
\text { ature }\end{array}$ & $\begin{array}{c}\text { Precipi- } \\
\text { tation }\end{array}$ & Flood & SI & Drought & $\begin{array}{l}\text { Land- } \\
\text { slide }\end{array}$ & Storm & Average & Max \\
\hline Weig & & 0.15 & 0.07 & 0.18 & 0.23 & 0.15 & 0.08 & 0.13 & & \\
\hline BinhMinh & Current & 1 & 1 & 2 & 0 & 1 & 0 & 1 & 0.86 & 2 \\
\hline town & 2020 & 1 & 1 & 3 & 1 & 1 & 0 & 1 & 1.27 & 3 \\
\hline & Current & 2 & 1 & 2 & 0 & 1 & 0 & 2 & 1.14 & 2 \\
\hline Binh Tan & 2020 & 2 & 1 & 3 & 1 & 1 & 0 & 2 & 1.55 & 3 \\
\hline & Current & 1 & 1 & 3 & 2 & 1 & 0 & 4 & 1.89 & 4 \\
\hline Long Ho & 2020 & 1 & 1 & 3 & 3 & 1 & 0 & 4 & 1.89 & 4 \\
\hline & Current & 2 & 1 & 1 & 1 & 1 & 0 & 1 & 1.52 & 3 \\
\hline Mang Thit & 2020 & 2 & 1 & 2 & 0 & 1 & 0 & 1 & 1.70 & 3 \\
\hline Tam Binh & Current & 1 & 1 & 1 & 0 & 3 & 0 & 1 & 1.21 & 3 \\
\hline 1 am binn & 2020 & 1 & 1 & 2 & 2 & 3 & 0 & 1 & 1.62 & 3 \\
\hline & Current & 1 & 2 & 1 & 3 & 1 & 1 & 1 & 1.52 & 3 \\
\hline Tra On & 2020 & 1 & 2 & 2 & 3 & 1 & 1 & 1 & 1.70 & 3 \\
\hline VinhLong & Current & 1 & 1 & 1 & 1 & 3 & 0 & 1 & 1.21 & 3 \\
\hline city & 2020 & 1 & 1 & 2 & 2 & 3 & 0 & 1 & 1.62 & 3 \\
\hline Vunom & Current & 1 & 1 & 3 & 4 & 1 & 0 & 1 & 1.96 & 4 \\
\hline Vung Liem & 2020 & 1 & 1 & 3 & 4 & 1 & 0 & 1 & 1.96 & 4 \\
\hline & Current & 10 & 9 & 14 & 14 & 12 & 1 & 12 & & \\
\hline Total & 2020 & 10 & 9 & 20 & 18 & 12 & 1 & 12 & & \\
\hline
\end{tabular}

\section{Drought}

Drought often occurs at the end of winterspring crop and prolongs until the end of summer-autumn crop -low tide period (end of April). In 2015, drought affected about $30 \%$ of summer-autumn rice area (about 17,600 ha), most in Vung Liem $(5,000$ ha) and BinhTan (5,000 ha), followed by Tam Binh (4,600 ha), and Tra On district (3,000 ha). In 2020, the increase in temperature and decrease in precipitation in Vinh Long province would result in drought risk with undesirable impacts on agricultural sector (water shortage, SI, reduction of productivity, etc.).

\section{Other disasters}

Storm affected crops in Long Ho (about 102 ha) and Tam Binh (1 ha), resulting in damage of
7 billion VND, as well as fruit area in Tam Binh district (0.4 ha) [18].

To sum up, there has been the impacts of CC on the agricultural sector, especially (rice) planting sector in Vinh Long province till 2020.

Determining CC factors of concern and hotspot areas

Table 4 presented risk index to $\mathrm{CC}$ of the agricultural sector in Vinh Long province, especially due to flooding and SI, where Vung Liem and Long Ho district had the highest values corresponding to 1.96 and 1.89 (Fig 3a),

By 2020, flooding and SI tend to increase, leading to the increase in risk level of the agricultural sector. Risk index of other factors would not be significantly changed. Vung Liem and Long Ho district should be taken into pay special attention (Fig 3b, Table 4). 

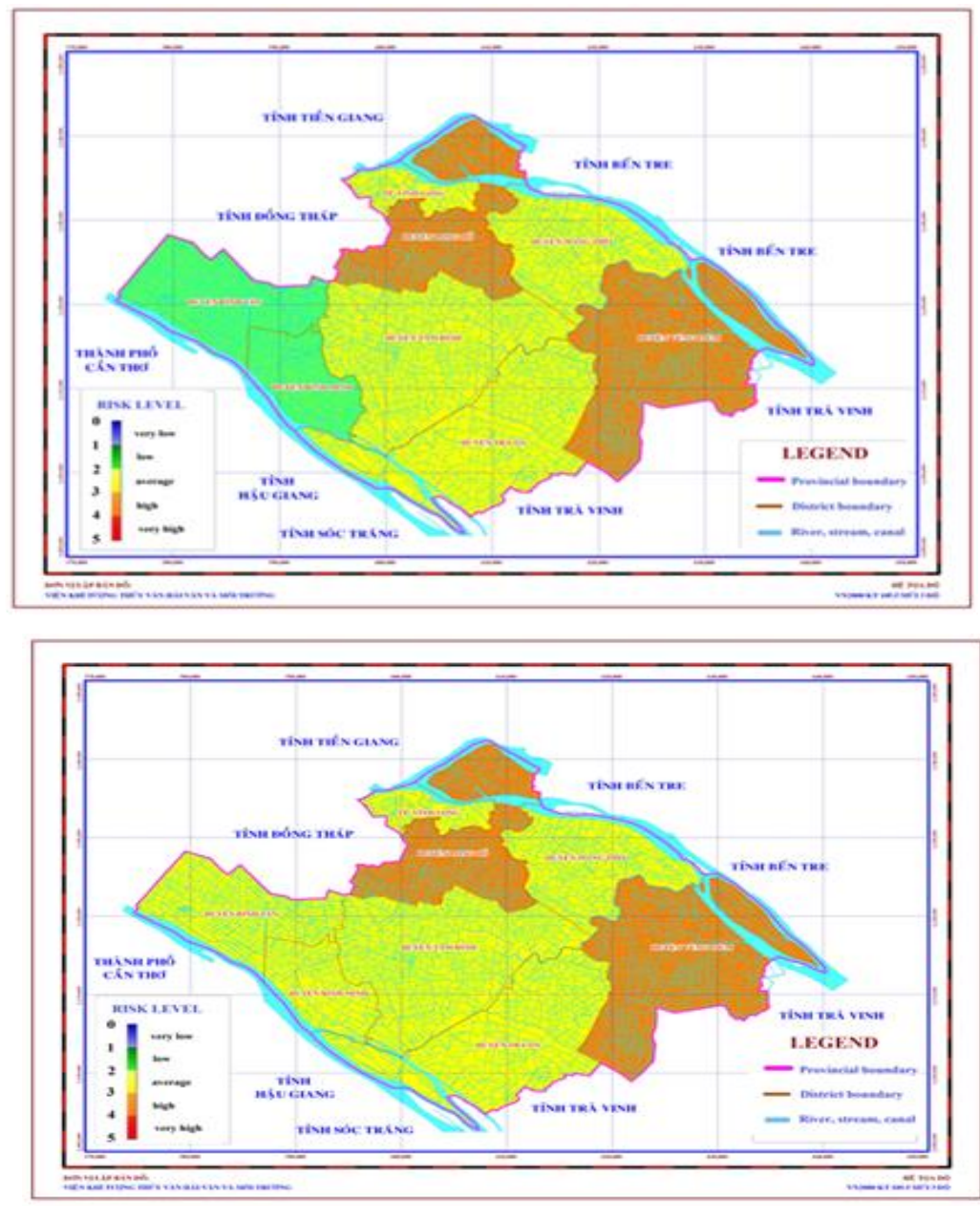

(b)

Fig. 3 The max CC risk index of the agricultural sector in Vinh Long province: (a) current status, (b) 2020

Table 5. Strenghts, weaknesses, opportunities, and threats of agricultural sector in Vinh Long province in the context of CC

\begin{tabular}{|c|c|c|c|}
\hline \multicolumn{2}{|r|}{ S - Strenghts } & \multicolumn{2}{|r|}{ W - Weaknesses } \\
\hline $\mathrm{S} 1$ & $\begin{array}{l}\text { Taking advantages of alluvium from Tien River and Hau } \\
\text { River [22] }\end{array}$ & W1 & $\begin{array}{l}\text { Hollow terrain and relative low (high risk of tidal } \\
\text { flooding) }\end{array}$ \\
\hline $\mathrm{S} 2$ & $\begin{array}{l}\text { Located in the center of Mekong Delta, facilitating trade } \\
\text { (including agricultural products) }\end{array}$ & W2 & $\begin{array}{l}\text { Complex river system; Being affected by semi- } \\
\text { diurnal tide (risk of SI) }\end{array}$ \\
\hline $\mathrm{S} 3$ & $\begin{array}{l}\text { Considerable land fund for agricultural development (about } \\
79 \% \text { of natural area) }[17]\end{array}$ & W3 & $\begin{array}{l}\text { Difficulties in mobilizing social resources to invest } \\
\text { in the agricultural sector [23] }\end{array}$ \\
\hline $\mathrm{S} 4$ & $\begin{array}{l}\text { Investing irrigation system and dikes to prevent flood, } \\
\text { riverbank landslide, etc [23] }\end{array}$ & W4 & $\begin{array}{l}\text { Less capital to invest in seeds, animals, and } \\
\text { infrastructure for agricultural development [23] }\end{array}$ \\
\hline S5 & $\begin{array}{l}\text { Investing water supply infrastructure, increasing the closed } \\
\text { and proactive irrigation area (about } 90 \% \text { of the agricultural } \\
\text { area) [23] }\end{array}$ & W5 & $\begin{array}{l}\text { Limitation in mechanization of production and } \\
\text { harvest as well as application of advanced } \\
\text { technologies in the pre-processing, preserving, and } \\
\text { processing [23] }\end{array}$ \\
\hline S6 & $\begin{array}{l}\text { Focusing on animal and seed farms to provide high-yield } \\
\text { and good quality varieties [23] }\end{array}$ & W6 & Difficulties in accessing information of CC [22] \\
\hline S7 & $\begin{array}{l}\text { Restructuring the agricultural sector in the period of } 2014- \\
2020[21]\end{array}$ & W7 & $\begin{array}{l}\text { Lack of adequate attention of CC response in a } \\
\text { number of state authorities [22] }\end{array}$ \\
\hline S8 & $\begin{array}{l}\text { Medium adaptive capacity to } \mathrm{CC} \text { of the community and } \\
\text { local authorities [22] }\end{array}$ & W8 & $\begin{array}{l}\text { Low effective implementing the CC response action } \\
\text { plan in some local [22] }\end{array}$ \\
\hline \multicolumn{2}{|r|}{ O - Opportunities } & \multicolumn{2}{|r|}{ T - Threats } \\
\hline
\end{tabular}




\begin{tabular}{|c|c|c|c|}
\hline $\mathrm{O} 1$ & $\begin{array}{l}\text { Taking advantages of temperature increase and dry season } \\
\text { prolonging to dry agricultural products, etc. }\end{array}$ & $\mathrm{T} 1$ & $\begin{array}{l}\text { Flooding is a matter of concern for the agricultural } \\
\text { sector and tends to be more seriously. }\end{array}$ \\
\hline $\mathrm{O} 2$ & $\begin{array}{l}\text { Mobilizing finance to cope with CC from the government, } \\
\text { local authorities, and international sources (ODA, AFD, } \\
\text { New Zealand Partnerships for International Development } \\
\text { Fund, etc) }[23,24]\end{array}$ & $\mathrm{T} 2$ & $\begin{array}{l}\text { SI significantly affected the agricultural production } \\
\text { in Long Ho, Tra On, Vung Liem district and tend to } \\
\text { increase in the future }\end{array}$ \\
\hline $\mathrm{O} 3$ & $\begin{array}{l}\text { Taking advantages of studying and transferring technology } \\
\text { from other provinces to improve adaptive capacity to CC of } \\
\text { the agricultural sector [23] }\end{array}$ & T3 & $\begin{array}{l}\text { Limited investment from the Government in the } \\
\text { provincial agricultural sector [23] }\end{array}$ \\
\hline & & $\mathrm{T} 4$ & $\begin{array}{l}\text { Increase in competition of agricultural products with } \\
\text { other prvinces [23] }\end{array}$ \\
\hline
\end{tabular}

Strenghts, weaknesses, opportunities, and Threats of the agricultural sector in the context of $\mathrm{CC}$

The relationships of $\mathrm{S}, \mathrm{W}, \mathrm{O}$, and $\mathrm{T}$ of the agricultural sector in Vinh Long province in the context of CC (Table 5) are following:

(i) S1, S2, S3 + O1: Maximizing the strengths of natural conditions and geographical position to maintain the growth rate of agricultural sector.

(ii) S6 + O3: Promoting the cooperation with research institutes, universities, companies from other provinces in studying and constructing seed and animal farms able to adapt to CC (increasing tolerance to salinity ...).

(iii) $\mathrm{S} 7+\mathrm{O} 2$ : When restructuring the agricultural sector, $\mathrm{CC}$ should be taken into consideration; promoting capital mobilization, creating financial sources in order to effectively respond to $\mathrm{CC}$.

(iv) $\mathrm{S} 8+\mathrm{O} 2$ : Leveraging national and international funds to improve $\mathrm{CC}$ adaptive capacity of community via communication programs.

(v) S4, S5 + T1, T2: Maintaining and constructing new irrigation systems to prevent salinization and inundation; investment in developing water supply infrastructure; enhancing closed and proactive irrigation area in the context of salinization increase.

(vi) S8 + T1, T2: Enhancing communication activities to improve the awareness, responsibilty, and participation of communities and authorities in the mission of $\mathrm{CC}$ response in the province.

(vii) $\mathrm{W} 4+\mathrm{O} 2$ : Strengthening and taking full adventages from support capitals to increase the investment in plant and animal varieties adapting to $\mathrm{CC}$ and infrastructures for agricultural development.

(viii) $\mathrm{W} 5+$ O3: Strengthening the mechanization of production, harvest; applying advanced technologies to improve quality of agricultural products and increase market competitive capability, especially in the context of CC.

(ix) $\mathrm{W} 6+\mathrm{O}_{2}$ : Taking full advantages from support capitals to increase the capability of community in accessing information of $\mathrm{CC}$ via communication activities.

(x) W7, W8 + T1, T2: Proposing solutions and timeline to implement $\mathrm{CC}$ response action plan, focusing on flood and SI impacts on the agricultural sector and cooperations among related organizations.

Besides, the following solutions are needed considering and applying:

(xi) Improving management capacity of local agencies in response to $\mathrm{CC}$.

(xii) Cooperation of 4 important parties, including farmers, government, scientists, and entrepreneurs in agricultural production and consumption; strengthening trade promotion and agricultural product brand.

(xiii) Developing policies to attract the investment in the agricultural sector, large-scale and high-tech agriculture development, and CC adaptation. Focusing on studying and applying scientific and technological achievements, especially in bio-technology to produce crops and livestock breeds suitable to local climate conditions.

(xiv) Mobilizing social resources to invest in agricultural infrastructure, taking into account $\mathrm{CC}$ factors.

(xv) Take advantages of high temperature to diversify the ways of processing agricultural products and to save energy.

(xvi) Applying science and technology, cleaner production technologies, fewer greenhouse gas emissions in preliminary processing, storage and processing stages to enhance the brand of agricultural products as well as to contribute to CC mitigation.

In summary, solutions to increase the response capacity to CC of the agricultural sector in Vinh 
Long province should be focused on adaption measures $(\mathrm{i}-\mathrm{xiv})$ and then mitigation ones (xv, xvi).

\section{CONCLUSION}

The research aimed at assessing $\mathrm{CC}$ impacts on agricultural sector in Vinh Long province till 2020. Rice was found to be the most affected object, mainly by flooding, SI, followed by extreme temperature, where Vung Liem, Long Ho, Binh Tan district, etc. should be of concern.

Besides, this study analyzed strengths, weaknesses, opportunities, and threats of agricultural sector in relation to $\mathrm{CC}$, measures to improve the adaptive capacity to $\mathrm{CC}$ were suggested, contributing to ensure the effective production, food security and sustainable development.

\section{REFERENCES}

[1]. . Thuc, N.V. Thang, H.T.L. Huong, M.V. Khiem, N.X. Hien, D.H. Phong, "Climate change and sea level rise scenarios for Vietnam" (Kịch bản Biến đổi khí hậu và nước biển dâng cho Việt Nam), Viet Nam Publishing House of Natural Resources, Environment And Cartography, 2016, [Online]. Available: http://www.imh.ac.vn/files/doc/KichbanBDKH/KBBDK H_2016.pdf

[2]. L.N. Thuy, P.D. Nam, "Impacts of climate change on agricultural production and migration of farmers" (Tác động của biên đổi khí hậu đến hoạt động sản xuất nông nghiệp và di cư của người nông dân), Journal of Sociology, 1, 129, pp 82-92, 2015.

[3]. N.M. Dung, "Climate Change and Agricultural Production in the Red River Delta: Current Status and Solutions" (Biến đổi khí hậu và sản xuất nông nghiệp vùng Đồng bằng sông Hồng: Thực trạng và Giải pháp), Journal of Economics and Development, 159, pp 27-34, 2010.

[4]. P.K. Thornton, M. Herrero, H.A. Freeman, A.M. Okeyo, E. Rege, P.G. Jones, PJ. McDermott, "Vulnerability, climate change and livestock-opportunities and challenges for the poor", Journal of Semi-Arid Tropical Agricultural Research,4, 1, pp 1-23, 2007.

[5]. Hoffmann, "Livestock Genetic diversity and Climate Change Adaptation". Proceedings International Conference: Livestock and Global Change, 2008, Cambridge University Press Tunisia, 2008, pp 76-80.

[6]. C.J. Garforth, "Impacts on livehoods, Livestock and global climate change". Proceedings International Conference: Livestock and Global Change 2008, Cambridge University Press Tunisia, 2008, pp 25-26.

[7]. L.X. Quang, "Methodology for assessing impacts of climate change on agricultural and rural infrastructure systems in Thua Thien Hue province" (Phương pháp đánh giá tác động của biến đổi khí hậu đến hệ thống cơ sở hạ tầng nông nghiệp và nông thôn tỉnh Thừa Thiên Huế), Journal of Water Resources Science and Technology, 22, pp 34-41, 2014.
[8]. D.V. Diem, T.D. Tri, N.T. Giang, "Forecasting impacts of climate change on rice production in Thai Thuy district, Thai Binh province" (Dự báo tác động của biến đổi khí hậu đến sản xuất lúa ở huyện Thái Thụy, tỉnh Thái Bình), Journal of Science and Development, 8, 6, pp 975-982, 2010

[9]. Pham Quang Ha, "Forecasting changes in rice productivity due to climate change impacts in the Mekong Delta and the Red River Delta" (Nghiên cứu dự báo thay đổi năng suất lúa do tác động của biến đổi khí hậu ở đồng bằng sông Cửu Long và đồng bằng sông Hồng), Proceedings of 2nd National Workshop on Science and Plants, 2012, pp 1180-1184.

[10].T.D. Hien, T.H. Thai, T.D. Hiền, T.H. Thái, "Assessing impacts of climate change on productivity and growth time of some agricultural crops in Da Nang" (Đánh giá tác động của biển đổi khí hậu đến năng suất và thời gian sinh trưởng của một số cây trồng nông nghiệp ở Đà Nẵng), Scientific and Technical Hydro - Meteorological Journal, 645, 41-45, 2014.

[11]. H.M. Hoang, V.P. D. Tri, "Impacts of climate change and available (surface) water resources for irrigation on rice yield in the alluvial and flooding-affected floodplain in the Tra Noc ward of Can Tho city" (Ảnh hưởng của điều kiện khí hậu và nước tưới thay đổi lên năng suất lúa ở phường Trà Nóc, thành phố Cần Thơ), Journal of Scicence Can Tho University, Part A: Natural Science, Technology and Environment, 39, pp 71-82, 2015.

[12].V.T. Huy, V.P.D. Tri, P.T. Vu, L.Q. Tri, N.H. Trung, "Application of Aquacrop model to simulate rice yield in the context of changing climatic factors in North of National Highway 1A, Bac Lieu province" (Ứng dụng mô hình Aquacrop mô phỏng năng suất lúa trong điểu kiện các yếu tố khí hậu thay đổi tại vùng Bắc quốc lộ $1 \mathrm{~A}$, tỉnh Bạc Liêu), Journal of Agriculture and Rural Development, 13, pp 48-51, 2013.

[13].N.T.M. Hanh, T.V. Ty, H.V.T. Minh, V.P.D. Tri, N.H. Trung, "Application of Cropwat model to evaluate rice yield in dike area of An Giang province in the context of changing hydro-meteorological factors" (Ứng dụng mô hình Cropwat đánh giá năng suất lúa vùng đê bao lửng tỉnh An Giang trong điều kiện biến đổi các yếu tố khí tượng thủy văn), Journal of Science, 24a, 187- 197, 2012.

[14].Vietnam Institute of Meteorology, Hydrology And Climate Change, "A Handbook of Assessing Impacts of Climate Change and Identifying Adaptation Measures" (Tài liệu hướng dẫn Đánh giá tác động của biến đổi khí hậu và xác định các giải pháp thích ứng), Viet Nam Publishing House of Natural Resources, Environment And Cartography, 2011, [Online]. Available: http://iasvn.org/upload/files/Q9ZR4TO78WHuong\%20da n\%20danh\%20gia\%20tac\%20dong\%20BDKH.PDF

[15].L.N.D. Khoi, "Community perceptions of the impact of climate change on agricultural production and response solutions" (Nhận thức của cộng đồng về tác động của biến đổi khí hậu đển sản xuất nông nghiệp và các giải pháp ưng phó), Journal of Science Hue University, 67, pp 2330, 2011

[16].M.V. Trinh, N.L. Trang, P.Q. Ha, "Develop assessment indices for impact of climate change on agricultural production (for field survey) (Xây dựng chỉ số đánh giá tác động của biến đổi khí hậu tới sản xuất nông nghiệp Việt Nam theo phương pháp điều tra), Journal of Vietnam Agricultural Science and Technology, 3, 24, 2011. [Online]. 
http://iae.vn/Data/upload/files/VanBan/publication/15_Ma iVanTrinh_BDKH_trinh(8-3-2013).pdf

[17]. Statistical Office of Vinh Long Province, "The Statistical Yearbook of 2015 of Vinh Long Province" (Niên giám thống kê tỉnh Vĩnh Long năm 2015), Vinh Long, 2016.

[18].People's Committee of Vinh Long Provine, "Natural Disaster Prevention and Search and Rescue Report of 2015" (Báo cáo kết quả phòng chống thiên tai và tìm kiếm cứu nạn năm 2015), Vinh Long, 2015.

[19].Intergovernmental Panel on Climate Change (IPCC), "Climate Change, Climate Change Impacts, Adaptation and Vulnerability, Summary for Policy Makers, Contribution of Working Group II to the Fourth Assessment Report of the Intergovernmental Panel on Climate Change", Cambridge University Press, Cambridge and New York, 2007.

[20].People's Committee of Vinh Long Provine, "The agricultural development plan of Vinh Long province until 2020" (Quy hoạch phát triển nông nghiệp tỉnh Vĩnh Long đến năm 2020), Vinh Long, 2012.
[21].People's Committee of Vinh Long Provine, "Report No. 249/BC-UBND of People's Committee of Vinh Long province dated 19/11/2014 on implementation of the Socio-Economic Development Plan of 2014; Socioeconomic development plan of 2015" (Báo cáo số 249/BC-UBND của UBND tỉnh Vĩnh Long ngày 19/11/2014 về Thực hiện Kế hoạch phát triển KTXH năm 2014; Kế hoạch phát triển KTXH năm 2015), Vinh Long, 2014.

[22].People's Committee of Vinh Long Provine, "Updating Climate change response action plan of Vinh Long province" (Cập nhật kế hoạch hành động ứng phó với biến đổi khí hậu tỉnh Vĩnh Long), Vinh Long, 2016.

[23]. Department of Agriculture and Rural Development of Vinh Long province, "Plan No 41/KH SC / PTNT dated $21 / 11 / 2014$ on medium-term public investment plan in 2016-2020", (Kế hoạch số 41/KH.SNN\&PTNT ngày 21/11/2014 về Đầu tư công trung hạn 5 năm 2016-2020), Vinh Long, 2014. 


\title{
Đánh giá tác động của biến đổi khí hậu đến lĩnh vực nông nghiệp tỉnh Vĩnh Long
}

\author{
Lê Ngọc Tuấn ${ }^{1}$, Trần Thị Thúy ${ }^{2}$ \\ ${ }^{1}$ Trường Đại học Khoa học tự nhiên, ĐHQG- HCM \\ ${ }^{2}$ Viện Khí tượng Thủy văn Hải văn và Môi trường \\ Tác giả liên hệ: Intuan@hcmus.edu.vn
}

Ngày nhận bản thảo: 10-04-2017, ngày chấp nhận đăng: 15-09-2017, ngày đăng: 10-08-2018

Tóm tắt - Biến đổi khí hậu là một thách thức lớn đối với nhân loại trong thế kỷ 21 , tác động tiêu cực đến nhiều ngành, nhiều lĩnh vực. Nghiên cứu nhằm mục tiêu đánh giá tác động của biến đổi khí hậu (BĐKH) đến lĩnh vực nông nghiệp tỉnh Vĩnh Long đến năm 2020 thông qua các phương pháp thu thập tài liệu và xử lý số liệu, GIS, ma trận đánh giá rủi ro, tham vấn chuyên gia và phương pháp SWOT. Các yếu tố được xem xét, đánh giá bao gồm ngập, xâm nhập mặn (XNM), hạn hán, sạt lở, giông lốc, nhiệt độ và lượng mưa. Kết quả đánh giá cho thấy các tác động đến ngành nông nghiệp tỉnh Vĩnh Long chủ yếu thông qua các yếu tố ngập, XNM và nhiệt độ, trong đó, cây lúa là đối tượng đáng quan tâm. Các địa phương có khả năng chịu nhiều ảnh hưởng là Vũng Liêm, Long Hồ và Bình Tân. Nghiên cứu cũng đề xuất một số giải pháp góp phần nâng cao năng lực ứng phó với $\mathrm{BĐKH} \mathrm{cho}$ ngành nông nghiệp, cung cấp cơ sở cho quá trình hoạch định các chính sách phát triển có liên quan tại địa phương.

Tù $\boldsymbol{k h o a ́}$ - nông nghiệp, biến đổi khí hậu, xâm nhập mặn, ngập lụt 